\title{
XXXIII. Account of an improved method of planting vines for forcing
}

\author{
Mr. Daniel Judd F.H.S.
}

To cite this article: Mr. Daniel Judd F.H.S. (1822) XXXIII. Account of an improved method of planting vines for forcing , Philosophical Magazine Series 1, 59:286, 122-124, DOI: $10.1080 / 14786442208652700$

To link to this article: http://dx.doi.org/10.1080/14786442208652700

里 Published online: 27 Jul 2009.

Submit your article to this journal $₫$

Џ Article views: 2

Q View related articles $\asymp$ 
of the rock exceedingly steep and abrupt ; the depth of water at a few yards distance, from nine feet to twenty-five; and a little further off to about nine fathom, which is the greatest depth of water between the rock and the shore; the rock itself appears to be of a sharp and hard kind, much indented, and full of crevices, as small anchors or grapplings which have been made use of by boats to anchor on it, as well as the leads used in sounding the depth, have in general been extricated therefrom with much difficulty; and from the circumstance of the rock not appearing to increase in magnitude, it is most probably not of the description of coral rock so frequent in the Indian sea.

Although alluded to and taken notice of in some old Dutch manuscript charts and surveys, this rock appears to be but very little known in general, and few, if any, of the English charts take notice of it at all. One of the latest editions of that valuable work of Captain Horsburg, Hydrographer to the Honourable East India Company, mentions it; but as the same is contained in an appendix to the second volume of the work, the circumstance there is no doubt often escapes observations. A transport with troops making the roads of Colombo in the year 1819, passed within a short distance of it, not aware of the danger; and some years since a large and valuable East Indiaman stood close in shore and tacked several times close to it, and passed between it and the shore without being aware that such a rock existed.

Colombo, Aug. 8, 1821.

XXXIII. Account of an improved Method of planting Vines for Forcing. By Mr. DANIEL JUDd, F.H.S.*

$\mathbf{H}_{\mathrm{H}}$ FREWITH I send an account of my management of the vines in the garden of Charles Campbell, Esq. of Edmonton, of which I have the charge.

My compost was formed as follows: In the winter of 1817, I procured a quantity of the top-spit of soil from a common in the neighbourhood, which consisted of a rich loam, rather inclining to be gritty, which property I prefer, because it gives a porousness to the compost, thereby allowing the water to pass freely through it. At the same time I collected some lime rubbish, well broken to pieces and sifted, some old tan, some leaf mould, and a quantity of the richest old dung I could select from the forcing-beds and elsewhere.

These materials having been kept separate, and frequently turned over in the summer, were nixed together in the autumn

* From the Transactions of the London Horticultural Socicty. 
of 1818, in the following proportions: one-half of loam, onefourth of dung, and one-fourth of line rubbish, united with the tan and leaf-mould. They were well mixed, by frequent turnings (but were not sifted) during the winter, when the weather was frosty or dry, for this operation should never be performed in wet weather.

It may be noticed, that I did not use so much dung in my compost as is sometimes done ; for I have observed that an excess of it retards the growth of the vine, notwithstanding it is considered to be a plant which will bear an extraordinary quantity of manure. The addition of old tan to the compost, which is not usual, I recommend, because $1 \mathrm{know}$, from experience, that the vines will root in that more freely than in any other substance.

In March last, the border, in front of the vinery, was cleared to the depth of upwards of three feet, below which it was drained, and then filled up with the new compost to the level of the bottom plate of the house; this was done in fine weather, and the new mould had full two months time to settle well before the young vines were planted in it.

My vine plants were raised from single eyes in March 1818; they were treated in the usual way through the summer, and kept from the frost during winter, until March last, when they were cut down to one eye, and placed in the pine-pit in order to produce young shoots of sufficient length to draw into the house at the time of planting. After they had made shoots about two feet long, they were removed to the green-house (which was at that time kept at a temperature of about $60^{\circ}$, for some other purposes); here they continued growing, till they had attained to the length of three or four feet; by this treatinent the whole plant was rendered more hardy, and consequently more fit for its final removal into the open border.

Early in May, having made good the height of the border quite to the level of the holes where the plants were to be carried into the house, so that no part of their stem should be exposed to the external air, I ovened the holes, for the reception of the plants, leaving them open upwards of a week, to remove any noxious quality in that part of the compost which would first receive the roots.

My plauting was executed on the I3th of May; but I consider that any period between the 10th of May and loth of June will be equally successful, provided the work be dose in seasonable weather, that is, when it is neither wet nor cold.

At the time of planting, I turned into each hole, a common wheel-barrow full of very old tan from the pine-house, in the middle of which tan the roots of my vine plants remained after Q2 
the plants had been treated as I shall now describe. I first cut off the leaves from the lower part of the plant, about two feet and a half of its length, leaving about an jnch of the footstalk of each on the plant, the end of which was then drawn very carefully through the hole, under the plate, without injuring the tender part of the shoot; the pot being removed, the ball or root of the plant was placed two feet distant from the front of the house, upon its side, so that the stem lay in a horizontal position, about six inches below the level of the surface of the border. When thus placed, the whole of the stem which was to be covered was slit or tongued, at each eye, like a carnation layer, by passing a sharp $k n$ ife at three-quarters of an inch below each eye, and on the side of the eye, about one-third of the thickness into the wood, and then upwards to the centre of the joint. This being done, the stem was covered with about four inches of old tan, and the other two inches were filled up with the mould of the horder. It is essential to the safety of the plant that the slitting be done the last thing, and whilst it is laid in its position, lest the stem should be broken.

The effect of the operation of slitting the stem is the production of abundance of roots from every eye; the progress is not very great until the roots begin to push out: after these shoot, it is surprising how fast the vines grow.

$I$ gave a little fire in the house for the first month after planting, though sparingly, and air was admitted into it continually, until the plants had got sufficient hold of the border; air was then admitted in the day, but the house was shut uy at night. Under this treatment, the shonts of the present season of these young plants are from twenty-five to thirty feet long, and their strength is fully proportionate to their length.

It is not my intention to grow any thing on the border, which will exhaust it, or deprive the vines of their full nourishment. To protect their roots in the winter, I shail use a covering of old tan, about six inches thick, which I prefer to dung or mulch of any description.

1 have this season planted vines in the same way, in other houses, besides the one I have now mentioned, and with equal success.

XXXIV. Report from the National Vaccine Estallishment. To the Right Honourable Robert Peed, Principal Secretary of State for the Home Department.

V National Vaccine Estahlishment, Percy Street, Jan. 31. Sir,- $V_{\text {accination has now been submitted to the test of an- }}$ other year's experience, and the result is an increase of our con- 